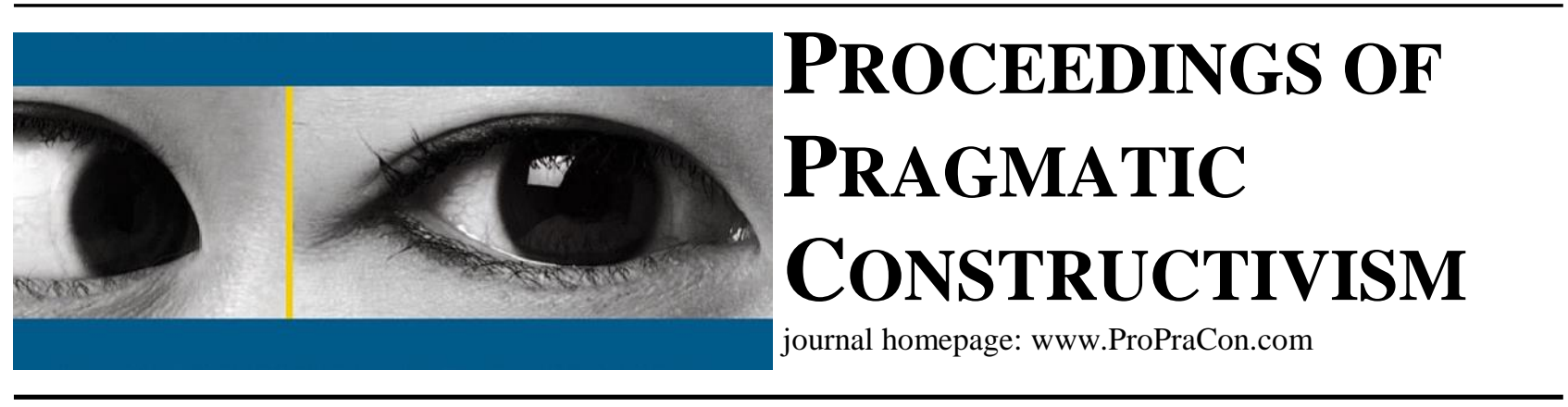

\title{
Perspectives to management language games and social interaction in self-managing organizations
}

\author{
Tuomas Korhonen \\ Tampere University, Cost Management Center, Finland \\ tuomas.korhonen@tuni.fi \\ Teija Ahopelto \\ Tampere University, Social Psychology, Finland \\ Teemu Laine \\ Tampere University, Cost Management Center, Finland \\ Johanna Ruusuvuori \\ Tampere University, Social Psychology, Finland \\ Sanni Tiitinen \\ Tampere University, Social Psychology, Finland
}

\begin{abstract}
This essay identifies a theoretically interesting area, i.e. language and social interaction in self-managing organizations. By building upon earlier work in Wittgensteinian language games, we show that despite some existing research on management language games (inside and outside pragmatic constructivism), not much is known about language games in self-managing organizations. The essay brings together ideas concerning language games in general management and pragmatic constructivism, making a novel contribution in the area. Furthermore, we present an ethnomethodological perspective on analysing language and social interaction: conversation analysis (CA). We suggest that CA could be utilized to analyse social interaction within self-managing organizations in more detail, showing how the specific institutional characteristics of this type of organization are talked into being in this particular context. Several further research questions are proposed for future studies in management language games and language and social interaction.
\end{abstract}

Keywords: self-managing organization, decentralized organization, language and social interaction, conversation analysis, pragmatic constructivism

\section{Introduction}

Some organizations have questioned the necessity of having bureaucracy and hierarchies as a basis for managing and controlling employees. The background for the "freedom-responsibility nexus" lies far in the history, in the thoughts of Aristotle and Plato, for instance, on free will (Dierksmeier, 2011). In today's world, how people organize themselves represents the current worldview - similarly as the different ways of organizing have represented the worldviews of earlier decades, centuries and millennia (Laloux, 2014, p. 15). Human organizations have evolved from 
the less organized prehistoric times, to tribes that followed shamans or elders; later "proto-empires" with violent exercise of power to control people; first civilizations and states and religious institutions with clear-cut rules; the Age of Enlightment and Industrial Revolution, the leader-follower type “corporate life” leading to pursuit for "achievement and success” for organizations and individuals alike; and finally, organizing for greater purposes, e.g. in non-profits (Laloux, 2014, pp. 15-32).

During the past decades, some organizations have started to focus on front-line decision-making and organizational culture instead of rulebooks, representing a type of organizing that is less hierarchical (Laloux, 2014, p. 32). The coordination of individuals' work has moved from domination to empowerment and from sticks to carrots i.e. from managing individuals to making these individuals self-managed (Laloux, 2014, p. 27). Similarly, organizational theorists have been - already since 1940s - questioning centralized control systems that are less democratic and less participative; with a flood in research papers in the area already decades ago, and numerous academic studies on self-managing teams and organizations (Barker, 1993; Martela, 2019).

Particularly in recent times, the ethos of downplaying the superior-subordinate structure has become unexpectedly common (see e.g., Laloux, 2014; Lee \& Edmondson, 2017). Prior research has identified the less hierarchical organizing to fall into streams of "post-bureaucratic organizations, humanistic management and organizational democracy" (Lee \& Edmondson, 2017, p. 35). The idea of questioning the traditional hierarchical structure creates a fundamental shift in how organizations are managed. Whereas a more traditional, hierarchical organization might perform well in terms of responsibility structures and unambiguous scopes of people’s tasks, an organization without such structures might benefit from flexible and quick decision-making practices, empowerment of employees and even lower administrative costs (Barker, 1993). While both ways of organizing - the hierarchical and the less hierarchical one - unquestionably involve some kind of rhetoric (cf., Cheney et al., 2004), in this essay we claim that they also involve some kinds of language games to construct the specific organizational setting and the practices involved (Wittgenstein, 2009; Henriksen et al., 2004; Nørreklit H., 2017; Henriksen, 2019).

However, which types of language games are used within organizations to support self-managing organizations is yet to be examined. Wittgensteinian language games can be defined as "the whole consisting of language and the activities in which it is woven” (Wittgenstein, 2009, p. 8e) and are a way to understand how language and action work in context (Henriksen et al., 2004). As Nørreklit L. (2017, p. 34) puts it: "the concepts of fact, possibility, and value in language games is a guideline with which we can illuminate how these dimensions function in our construction of the actor-reality relationship". Thereby, in this essay we take the stance that "meaning in language must be found in its use. Meaning is not given by any external referent but by the practical usage of language in specific social settings. Language, in this understanding, does not consist of one overarching stable system [...] but rather by a multitude of locally constituted language games in which meaning is constructed, negotiated and learned” (Kure et al., 2017, p. 216).

Importantly, to "understand the language games in an organisation is to understand the organisation - as language games are the link between individual realities and social realities” (Henriksen et al., 2004, p. 36). Thereby, there is an important connection between the type(s) of organizing action and language(s) used. If we wish to understand the prerequisites of functioning self-managing organizations (Martela, 2019), language is clearly something where researchers need to take a look at.

This essay paves the way for this area of research that we see interesting to academic researchers working on pragmatic constructivism and language games (e.g., Henriksen et al., 2004; Nørreklit et al., 2006; Nørreklit, 2011; Nørreklit et al., 2016; Kure et al., 2017; Nørreklit H., 2017; Henriksen, 2019) and self-managing organizations (e.g., Hamel, 2011; Lee \& Edmondson, 2017; Martela, 2019; O’Grady, 2019). Indeed, we propose that researchers should start examining the research area of language enacting self-managing organizations. Moreover, we see that practitioners working in (or planning to build up) self-managing organizations could be inspired by our thoughts. We warmly welcome discussions with both of these audiences, the academic and practitioner ones.

To introduce why and how we believe language enacts self-managing organizations, we approach this theme with two types of language and social interaction perspectives (LeBaron et al., 2003; Maynard \& Peräkylä, 2006). First, we will present in more detail the perspective of Wittgensteinian language games and its usefulness when defining research questions related to the enactment of self-managing organizations. Importantly, we acknowledge that language games have been a widely examined research topic in the area of pragmatic constructivism. Then, we will introduce the theory and methods of conversation analysis (CA) (Sack et al., 1974; Heritage 1984; Heritage, 2008; Sidnell \& Stivers, 2013) to illustrate the importance and potential of analyzing language use in authentic interaction situations when striving to understand how the organizations with less hierarchy are talked into being (cf. Heritage \& Clayman, 2010).

These two perspectives are interested in actual language use in real-life settings. However, they differ in whether they try to make conclusions on the studied actors' intentions or not. Values and intentions are central in pragmatic constructivist language games in particular (Trenca, 2016; Trenca \& Nørreklit, 2017) as a part of the actor-reality construction. This is the case although values and intentions are difficult to observe (Nørreklit L., 2017). Conversely, in CA, focus is explicitly on interaction and what we can learn about it from what is actually observable (see LeBaron et al., 2003; Maynard \& Peräkylä, 2006, p. 245). Also CA, however, sees that values do exist - they are just not the focus 
of analysis. This stems from two interrelated points: a) CA acknowledges that through solely observing what happens in interaction, we cannot reliably get access to people's thinking, and 2) interaction is filled with regularities that are not dependent on people's intentions or values - and CA studies are specifically interested in those regularities.

We claim that the two perspectives could be perceived as mutually supplementary. On the one hand, CA provides a way to examine action at the micro level possibly in ways not previously seen in studies of language games, particularly under pragmatic constructivism. Pragmatic constructivism, on the other hand, provides a perspective to integrate the observed actions into their social and psychological context that is not directly observable. This social and psychological - context is influenced by facts, possibilities, values and communication (Nørreklit et al., 2006; Jakobsen et al., 2011; Nørreklit et al., 2010; Nørreklit H., 2017) and could grasp actors’ intentionality by using various sources of data to supplement CA.

However, pragmatic constructivist researchers should be aware of not jumping to conclusions about actors' intentionality or subjective values either. CA, therefore, also could inspire us to sets boundaries to how we empirically understand the actor-reality construction in specific contexts and thereby point to an important area for pragmatic constructivist researchers to develop further . If values are not “directly” and constantly “observable” in people’s actions (Nørreklit L., 2017, p. 45), also pragmatic constructivists should be reflective towards what kinds of datasets are needed to be able to work out people's thinking related to specific contexts and specific situations, with specific actors involved. We can depart from the idea that "basic values reveal themselves in the strivings and preferences of the actor" (Nørreklit L., 2017, p. 45), and develop that idea further. Figure 1 summarizes our line of thought.

Figure 1. The problem of drawing insights on actors' values from observation.

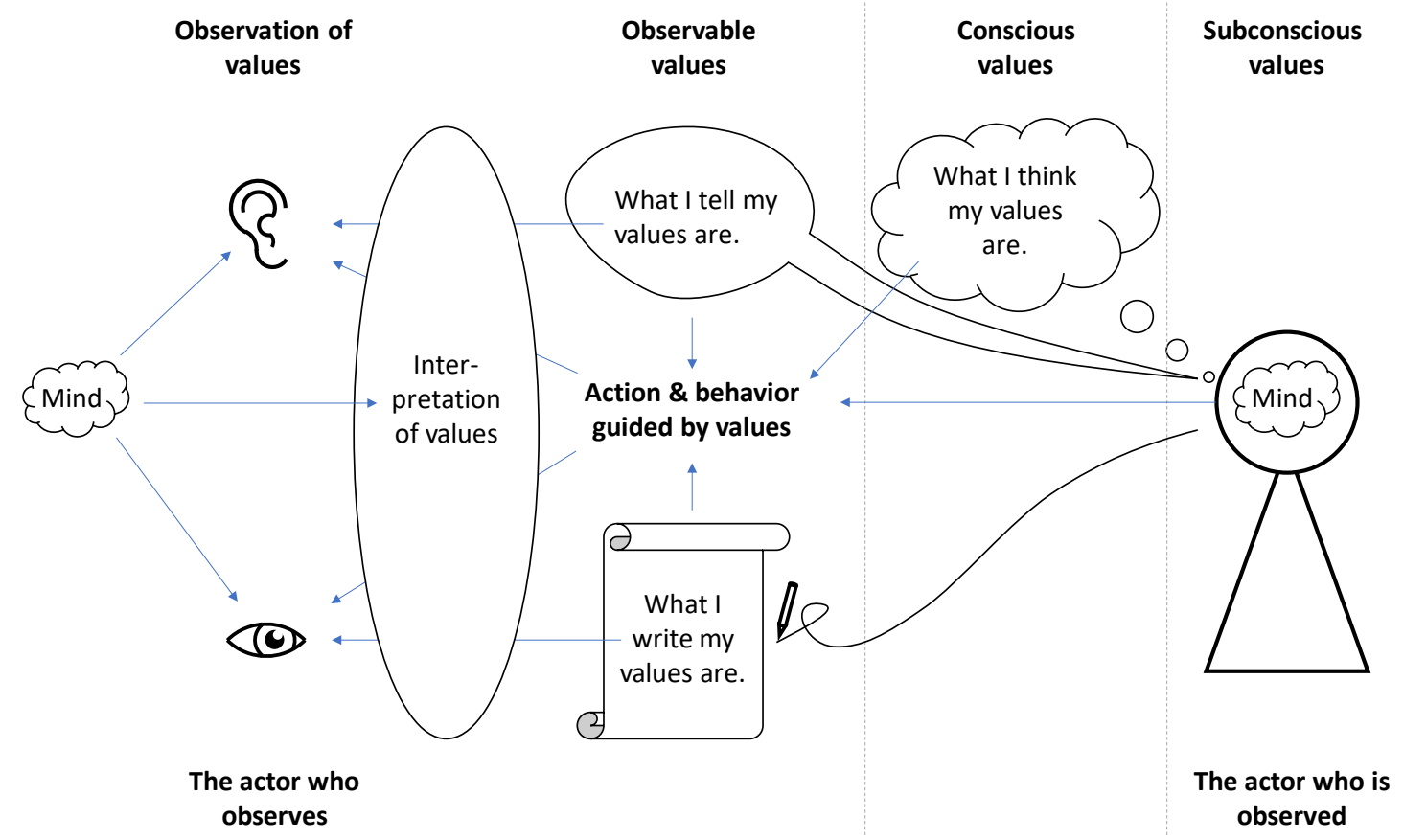

In sum, instead of examining, e.g. how actors in a less hierarchical organization are influenced by the particular organizational structure, we focus on how they use language to build the organization as a less hierarchical one (see e.g., Heritage \& Clayman, 2010). In the following, we will present language games and CA in more detail, focusing on how these approaches are related to organizational structures.

\section{Language games in the analysis of organizational structures}

Theories of management language games have already been present in the literature (see e.g., Pondy, 1989; Kelly, 2008). Such theories can provide us understanding about "how meanings are established and what it means to communicate” (Pondy, 1989, p. 232). One of such theories is presented by Astley and Zammuto (1992), who suggest that: "Managers participate in their own language game. [...] the primary function of the managerial language game is to facilitate practical action. Managers espouse their own "theories" about the way their world works and the conceptual language they use establishes a context within which organizational life is constructed and reconstructed. Organizations 
are created and sustained as managers engage their surroundings through the use of linguistic codes and conventions that define appropriate patterns of social activity [...] The role of management, consequently, becomes one of using words and ideas to shape conceptions of organizational reality” (p. 449-450). In traditional company life and the language therein, a hierarchical organization might use terms like "chain of command", "first line superior", or refer more colloquially to "bosses" or "the management", to construct certain relations between individuals, group them, give them tasks and control them. These terms are language games in use for managing people. However, a hierarchical organization structure does not necessitate oppressive use of language but also metaphors and storytelling can be used to motivate workers (Nørreklit, 2011).

In comparison to the traditional managerial model, in self-managing organizations, decision-making is formally and systematically decentralized throughout the organization. An organization is defined as self-managing when decision making rights are decentralized in the organizational structures and operating modes and teams can make decisions independently without being recycled by management. (Lee \& Edmondson, 2017) We expect that a language game present in managing an organization without the superior-subordinate structure would be quite different from the one of a hierarchical organization.

Thereby, we suggest this area to be further examined. Many unanswered questions remain. For example: how and through which channels is language used in everyday working life to enact those less hierarchical organizational forms? Which kinds of rulesets for language games can be identified in settings like these? How can managers support their employees' well-being by using language that enacts self-managing organizations? With the pragmatic constructivist understanding of language games it could be possible to examine how different actors' values and intentions become (at least partially) visible in the language games used in less hierarchical organizations - for the empathetic eye (Trenca, 2016; Nørreklit L., 2017; Trenca \& Nørreklit, 2017)? Moreover, how do managers use language to make possibilities known within a less hierarchical organization through communication (Nørreklit H., 2017)? Or which kinds of facts can actors rely on in organizations that have less hierarchy? How are these facts constructed in situations in which support from supervisors is perhaps more ambiguous than in the more traditional supervisor-subordinate relationships (Laine et al., 2016)?

Questions like these could be answered if researchers were granted access to how language is used in organizations that have less hierarchy. In the following section, we propose one way of analyzing data that could be quite enlightening in terms of understanding language enacting self-managing organizations, namely CA.

\section{Conversation analysis as a perspective to understanding organizational structures}

Although self-managing organizations do not have a traditional hierarchical structure, this does not inevitably mean the absence of hierarchies, or that the decision-making rights would be evenly distributed between all employees. With the CA approach within the language and social interaction perspective, we would be able to analyze closely the actual interaction situations in which decisions are made and the rights to make decisions negotiated between the organizational actors. By focusing on actual interaction, CA enables making the organizational practices, power structures and potential hierarchies visible as they are produced and oriented to by the actors (see e.g. Stevanovic \& Peräkylä, 2012).

One of the main principles of CA is that social interaction is inherently structurally organized in such ways that what happens in an interaction situation is not explicable by reference to actors' intentions or personal characteristics (Heritage, 1984, 241-242; see also Goffman, 1964). Another main principle of CA is that each turn of talk is seen both as shaped by the context created by the previous turns and as shaping the context for the following turns (Heritage, 1984, 241-242). As the two main principles are understood as being realized in the minute details of social interaction, it means that social interaction needs to be studied in such a way that does not make premature conclusions about what happens in interaction but foregrounds data-driven and systematic analysis of naturally-occurring recorded interaction (Heritage, 1984, 234-238; Sidnell \& Stivers, 2013). CA thus provides an empirically strong approach and method for making visible authentic interaction practices which are used to define roles, relationships and power structures in different types of settings, for example, in work communities and organizations (Clifton, 2006).

From CA perspective, potential arenas of “talking into being” (Heritage \& Clayman, 2010) a self-managing organization are, for example, meetings in which organizational actors plan and make decisions about the operations, products and businesses of the organization. These kinds of meetings can be viewed as institutional interaction. In CA literature, interaction is seen as institutional when the participants orient to performing some specific tasks to achieve goals related to their institutional roles such as, being a meetings participant, chair-person, manager, secretary etc. (Heritage \& Clayman, 2010). These institutional tasks are accomplished though talk-in-interaction, which includes both vocal and non-vocal resources ( such as talk, gaze, gestures, body postures, spatial location) (Arminen, 2016; Heath, 1986; Heritage \& Clayman, 2010). 
Altogether, we find that in an organization that is organized with less hierarchy (as in any organizational form containing human actors), any vocal or written interaction between employees would reveal how language is used in action to talk the self-managing organization into being. Indeed, we suggest that researchers need to investigate how employees interact to enact their less hierarchical organizational form. Further research could address questions like: How do actors show their authority in decision-making in a radically decentralized setting? How are organizational rules communicated and people controlled (O’Grady, 2019)? Or more specifically, how are certain institutional tasks, such as performance appraisal interviews, including complaints and other delicate issues, managed when hierarchies between managers and employees are not explicit (cf. Ruusuvuori et al., 2019)? How are rights and responsibilities with regard to various challenging situations distributed and negotiated on? How do people show agreement or disagreement if everyone has a somewhat equal vote in decisions, from more senior to more junior workers (cf. Tiitinen \& Lempiälä, 2018)? All these questions need to be studied in more detail. Conclusively, more academic research is needed in order to understand how people interact within self-managing organizations.

\section{Closing words}

To not have a hierarchy within an organization, is a language game itself, since managerial tasks actually do not disappear if there are no named managers (Barker, 1993). How do people interact in a self-managing organization then? This essay is an attempt to unveil a potential research area in the intersection of organizational theory, language and social interaction studies, and pragmatic constructivism.

By this essay, we depart from the priorly separate research areas of management language games and language games in studies of pragmatic constructivism. To our knowledge, this paper is the first attempt to connect the general management research and pragmatic constructivist research in this area. By this attempt, we hope to spark a theoretical debate on the applicability of the thoughts on language games in general management research (Pondy, 1989; Astley \& Zammuto, 1992; Kelly, 2008) in the area of pragmatic constructivism - and vice versa.

More particularly, this essay contributes to the literature on management language games (Pondy, 1989; Astley \& Zammuto, 1992; Kelly, 2008), by introducing the idea that management language games could be understood in more detail with a nuanced language and social interaction perspective, CA that focuses on language use in actual interaction. As our key contribution, we identify numerous research possibilities in the area, particularly linked to how pragmatic constructivism uses language games as a concept to capture human interaction (e.g., Henriksen et al., 2004; Kure et al., 2017; Nørreklit H., 2017; Henriksen, 2019).

Finally, the paper contributes to the literature of language and social interaction, by raising some important questions that require further inquiry. Importantly, we expect the perspective of language and social interaction to provide a high-resolution tool for understanding self-managing organizations. Examination of language and social interaction is needed for analyzing how people act in their various encounters at work, where the actual tasks of the organization are talked into being, in order to show, e.g. how emergent leadership takes place in less hierarchical organizations (Lee \& Edmondson, 2017; Salovaara \& Bathurst, 2018; Gerpott et al., 2019). By pointing out specific future research directions for studies of language and social interaction, the essay will hopefully be a starting point for studies in this area that is yet underexamined in the field of management, even more generally.

\section{Acknowledgements}

We would like to express our gratitude to Business Finland (Finnish government organization for innovation funding and trade, travel and investment promotion) for funding this piece of research.

\section{References}

Arminen, I. (2016). Institutional interaction. Routledge.

Astley, W. G., \& Zammuto, R. F. (1992). Organization science, managers, and language games. Organization Science, 3(4), 443-460.

Barker, J. R. (1993). Tightening the iron cage: Concertive control in self-managing teams. Administrative Science Quarterly, 38(3), 408.

Cheney, G., Christensen, L. T., Conrad, C., \& Lair, D. J. (2004). Corporate rhetoric as organizational discourse. The Sage Handbook of Organizational Discourse, 79-103. 
Clifton, J. (2006). A conversation analytical approach to business communication: The case of leadership. The Journal of Business Communication (1973), 43(3), 202-219.

Dierksmeier, C. (2011). The freedom-responsibility nexus in management philosophy and business ethics. Journal of Business Ethics, 101(2), 263-283.

Gerpott, F. H., Lehmann-Willenbrock, N., Voelpel, S. C., \& van Vugt, M. (2019). It's Not Just What is Said, but When it's Said: A Temporal Account of Verbal Behaviors and Emergent Leadership in Self-Managed Teams. Academy of Management Journal, 62(3), 717-738.

Goffman, E. (1964). The neglected situation. American Anthropologist, 66(6), Part 2: The Ethnography of Communication, 133-136

Hamel, G. (2011). First, let's fire all the managers. Harvard Business Review, 89(12), 48-60.

Heath, C. (1986). Body movement and speech in medical interaction. Cambridge: Cambridge University Press.

Henriksen, L. B. (2019). Language Games, Dialogue and the Other. Proceedings of Pragmatic Constructivism, 9(1), 25-30.

Henriksen, L. B., Nørreklit, L., Christensen, J. B., Jørgensen, K. M., \& O'Donnell, D. (2004). Dimensions of change: conceptualising reality in organisational research. Copenhagen Business School Press DK.

Heritage, J. (1984). Garfinkel and Ethnomethodology. Cambridge: Polity Press.

Heritage, J., \& Clayman, S. (2010). Talk in action: Interactions. Identities and Institutions, 44, John Wiley \& Sons.

Heritage, J. (2008). Conversation analysis as social theory. In. B. Turner (ed.), The New Blackwell Companion to Social Theory (p. 300-320). Oxford: Blackwell.

Jakobsen, M., \& Johansson, I. L. (2011). An Actor's Approach to Management: Conceptual Framework and Company Practises. DJøF Publishing.

Kelly, S. (2008). Leadership: A categorical mistake? Human Relations, 61(6), 763-782.

Kure, N., Nørreklit, H., \& Raffnsøe-Møller, M. (2017). Language Games of Management Accounting-Constructing Illusions or Realities? In H. Nørreklit (ed.), A Philosophy of Management Accounting (pp. 211-224). Routledge.

Laine, T., Korhonen, T., Suomala, P., \& Rantamaa, A. (2016). Boundary subjects and boundary objects in accounting fact construction and communication. Qualitative Research in Accounting \& Management, 13(3), 303-329.

LeBaron, C. D., Mandelbaum, J., \& Glenn, P. J. (2003). An overview of Language and Social Interaction Research. In P. J. Glenn, C. D. LeBaron, J. Mandelbaum (eds.), Studies in Language and Social Interaction. In Honor of Robert Hopper, 1-39. Mahwah: Lawrence Erlbaum Associates.

Lee, M. Y., \& Edmondson, A. C. (2017). Self-managing organizations: Exploring the limits of less-hierarchical organizing. Research in Organizational Behavior, 37, 35-58.

Martela, F. (2019). What makes self-managing organizations novel? Comparing how Weberian bureaucracy, Mintzberg's adhocracy, and self-organizing solve six fundamental problems of organizing. Journal of Organization Design, 8(1), 1-23.

Maynard, D. W., \& Peräkylä, A. (2006). Language and Social Interaction. In J Delamater (ed.), Handbook of Social Psychology, 233-258. New York: Springer.

Nørreklit, H. (Ed.). (2017). A Philosophy of Management Accounting: A pragmatic constructivist approach. Taylor \& Francis.

Nørreklit, H., Nørreklit, L., \& Mitchell, F. (2010). Towards a paradigmatic foundation for accounting practice. Accounting, Auditing \& Accountability Journal, 23(6), 733-758.

Nørreklit, H., Nørreklit, L., \& Mitchell, F. (2016). Understanding practice generalisation-opening the research/practice gap. Qualitative Research in Accounting \& Management, 13(3), 278-302.

Nørreklit, L. (2017). Actor-reality construction. In H. Nørreklit (ed.), A Philosophy of Management Accounting (pp. 23-71). Routledge.

Nørreklit, L., Nørreklit, H., \& Israelsen, P. (2006). The validity of management control topoi: towards constructivist pragmatism. Management Accounting Research, 17(1), 42-71.

O’Grady, W. (2019). Enabling control in a radically decentralized organization. Qualitative Research in Accounting \& Management, 16(2), 224-251.

Pondy, L. R. (1989). Leadership is a language game. In H. J. Leavitt, L. R. Pondy \& D. M. Boje (eds) Readings in managerial psychology, 224-233. The University of Chicago Press. Chicago and London.

Ruusuvuori, J., Asmuß, B., Henttonen, P., \& Ravaja, N. (2019). Complaining about others at work. Research on Language and Social Interaction, 52(1), 41-62.

Sacks, H., Schegloff, E., \& Jefferson, G. (1974). A Simplest Systematics for the Organization of Turn-Taking for Conversation. Language, 50(4), 696-735.

Salovaara, P., \& Bathurst, R. (2018). Power-with leadership practices: An unfinished business. Leadership, 14(2), 179202.

Sidnell, J., \& Stivers, T. (Eds.). (2013). The handbook of conversation analysis. John Wiley \& Sons. 
Stevanovic, M. \& Peräkylä, A. (2012). Deontic authority in interaction: the right to announce, propose, and decide. Research on Language and Social Interaction, 45(3), 297-321.

Tiitinen, S., \& Lempiälä, T. (2018). Two Social Functions of Stepwise Transitions When Discussing Ideas in Workplace Meetings. International Journal of Business Communication.

Trenca, M. (2016). Tracing the becoming of reflective practitioner through the enactment of epistemic practices. Qualitative Research in Accounting \& Management, 13(3), 350-369.

Trenca, M., \& Nørreklit, H. (2017). Actor-based performance management. In A Philosophy of Management Accounting (pp. 169-187). Routledge.

Wittgenstein, L. 2009. Philosophical investigations. John Wiley \& Sons. 